\title{
ANALISIS PENGARUH MODEL PEMBELAJARAN \\ BERBASIS MASALAH DENGAN MENGGUNAKAN MEDIA \\ FLASH DAN SIKAP ILMIAH TERHADAP KEMAMPUAN \\ BERPIKIR TINGKAT TINGGI FISIKA SISWA SMA
}

\author{
Despaleri Peranginangin dan Sahyar \\ Jurusan Fisika Pascasarjana Universitas Negeri Medan \\ Jln. Willem Iskandar Pasar V, Medan 20221
}

\begin{abstract}
Abstrak. Penelitian ini bertujuan untuk menganalisis (1) perbedaan kemampuan berpikir tingkat tinggi fisika siswa pada model pembelajaran berbasis masalah dengan menggunakan media flash dan pembelajaran konvensional, (2) perbedaan kemampuan berpikir tingkat tinggi siswa yang memiliki sikap ilmiah di atas rata-rata dan di bawah rata-rata, serta (3) interaksi antara model pembelajaran dengan tingkat sikap ilmiah dalam mempengaruhi kemampuan berpikir tingkat tinggi siswa. Penelitian ini merupakan penelitian quasi eksperimen. Pemilihan sampel dilakukan dengan teknik cluster random sampling sebanyak dua kelas, dimana kelas pertama diajarkan dengan model pembelajaran berbasis masalah dengan menggunakan media flash dan kelas kedua dengan pembelajaran konvensional. Instrumen yang digunakan terdiri dari tes kemampuan berpikir tingkat tinggi dan angket sikap ilmiah. Data dalam penelitian ini dianalisis dengan menggunakan anova dua jalur. Hasil penelitian menunjukkan bahwa kemampuan berpikir tingkat tinggi fisika menggunakan model pembelajaran berbasis masalah dengan menggunakan media flash lebih baik dibandingkan dengan pembelajaran konvensional, kemampuan berpikir tingkat tinggi siswa dengan sikap ilmiah di atas rata-rata lebih baik dibandingkan dengan siswa yang sikap ilmiah di bawah rata-rata, serta terdapat interaksi antara model pembelajaran berbasis masalah dengan menggunakan media flash dan sikap ilmiah dalam mempengaruhi kemampuan berpikir tingkat tinggi siswa.
\end{abstract}

Kata kunci: model pembelajaran berbasis masalah, media flash, sikap ilmiah, kemampuan berpikir tingkat tinggi

\section{ANALYSIS OF EFFECT PROBLEMS BASED LEARNING MODEL USING FLASH MEDIA AND SCIENTIFIC ATTITUDE TOWARD THE ABILITY TO THINK OF PHYSICS HIGHER LEVEL SMA'S STUDENTS}

\author{
Despaleri Peranginangin and Sahyar \\ Physics Education Program, Graduate State University of Medan \\ Jln. Willem Iskandar Pasar V, Medan 20221
}

\begin{abstract}
The aim of this research were to analyze the difference of student's high order thinking skills by using Problem Based Learning Model with media flash and conventional learning, the difference of student's high
\end{abstract}


order thinking skills who had above average and under average category in scientific attitude, and the interaction between learning model and the level of scientific attitude in influencing student's high order thinking skills. This research was a quasi-experimental research. The sample in this research was conducted by cluster random sampling of two classes, which the first class, as experiment class, was taught with Problem Based Learning Model with media flash and second class, as control class, with conventional learning. The research instrument consisted of high order thinking skills test and scientific attitude test. Data in this research was analyzed by using two way Anova. The result of the research showed that the physics high order thinking skills using Problem Based Learning Model with media flash was differ and show better results than the conventional learning, the physics high order thinking skills of students who had above average category in scientific attitude was differ and show better results than under average category, and there was interaction between Problem Based Learning Model with media flash and the level of scientific attitude in influencing student's high order thinking skills.

Keyword: problem based learning model, media flash, scientific attitude, high order thinking skill

\section{PENDAHULUAN}

Pendidikan memegang peranan yang sangat penting dalam mempersiapkan sumber daya manusia yang berkualitas. Pendidikan juga merupakan salah satu kebutuhan hidup manusia yang penting yang dapat meningkatkan harkat dan martabat manusia. Tanpa pendidikan manusia tidak akan dapat hidup dengan layak. Oleh karena itu pendidikan hendaknya dikelola dengan semaksimal mungkin baik dari segi sarana maupun prasarana. Dengan demikian pendidikan harus betul-betul diarahkan untuk menghasilkan manusia yang berkualitas dan mampu bersaing, disamping memiliki budi pekerti yang luhur dan moral yang baik.

Menurut Ayu (2013) bahwa pendidikan yang memiliki kualitas baik berawal dari pembelajaran di sekolah. Pembelajaran yang terjadi pada era saat ini adalah pembelajaran yang berpusat pada peserta didik. Siswa diharapkan aktif dalam pembelajaran di dalam kelas maupun di luar kelas. Selain keaktifan, siswa juga diharapkan mampu berpikir tingkat tinggi untuk menyelesaikan suatu masalah.
Siswa juga diharapkan mampu mengkombinasi pengetahuan lama dengan pengetahuan baru.

Pada proses pembelajaran sangat diharapkan terjadinya komunikasi dua arah antara guru dan siswa secara timbal balik, demi terjadinya interaksi belajar yang bagus sehingga membawa kepada pencapaian tujuan pembelajaran yang maksimal. Agar tujuan pembelajaran tersebut dapat tercapai, maka dalam proses pembelajarannya guru yang semula bertindak sebagai sumber belajar beralih fungsi menjadi seorang fasilitator kegiatan pembelajaran yang berperan mengarahkan dan membimbing siswa untuk memecahkan masalah-masalah yang dihadapi dalam belajar, sehingga mampu membangun motivasi dan meningkatkan aktivitas belajar siswa.

Pembelajaran fisika yang sering menjadi kendala diantaranya nilai fisika siswa relatif rendah. Menurut Surapranata dalam Muslim (2004) menyatakan rendahnya nilai fisika tidak terlepas dari adanya kecenderungan pada pembelajaran yang bersifat abstrak dan kurang bermakna. Kenyataan di lapangan pembelajaran fisika hanya mendorong siswa untuk menghafal 
konsep dan kurang mampu menggunakan konsep tersebut jika menemui masalah dalam kehidupan nyata yang berhubungan dengan konsep tersebut dalam Trianto (2009). Lebih jauh lagi, siswa kurang mampu memahami dan mengidentifikasi masalah, merumuskan masalah serta menentukan solusi-solusi untuk menyelesaikan masalah atau situasi baru yang dihadapi. Hal ini yang menjadikan sumber daya manusia Indonesia hanya sedikit yang berperan sebagai garda terdepan dalam dunia industri dengan pemikiran yang kritis dan inovatif, sedangkan sisanya hanya berperan sebagai buruh, pekerjaan yang tidak membutuhkan pemikiran mendalam.

Berdasarkan hasil dari TIMMS (Trend Of International On Mathematics And Science Study) diperoleh bahwa nilai akhir mata pelajaran Fisika masih sangat rendah. Prestasi sains siswa Indonesia pada TIMSS menempati peringkat 32 dari 38 negara (tahun 1999), peringkat 37 dari 46 negara (tahun 2003), dan peringkat 35 dari 49 negara (tahun 2007). Hasil analisis menunjukkan bahwa rata-rata kemampuan fisika siswa Indonesia pada tiap aspek kognitif (knowing, applying, reasoning) masih rendah. Rata-rata kemampuan kognitif knowing $(32,07)$ lebih tinggi dibandingkan dengan aspek kognitif applying $(35,11)$ dan reasoning $(22,23)$. Kecenderungan skor fisika siswa Indonesia terhadap standar Internasional dalam tiga tahun terakhir pada TIMSS adalah rendah. Skor ratarata fisika siswa Indonesia 34,57, masih di bawah rata-rata standar Internasional 43,40. Dari uraian di atas tampak bahwa nilai fisika siswa Indonesia pada TIMSS mengalami penurunan dari tahun ke tahun. Jika ditinjau dari aspek pemahaman, penerapan, dan penalaran dalam ranah kemampuan kognitif seperti yang diterapkan pada TIMSS, hal ini digunakan untuk menunjukkan bahwa hasil belajar dan kemampuan berpikir siswa negara pesertanya. Dari ketiga aspek tersebut, aspek reasoning (menalar) yang merupakan ciri kemampuan berpikir tingkat tinggi taksonomi Bloom mengalami penurunan tertinggi yaitu $4 \%$, sedangkan kedua aspek lain yang termasuk kemampuan berpikir tingkat rendah taksonomi
Bloom yaitu knowing (mengetahui) dan applying (mengaplikasikan) masing-masing mengalami penurunan $3 \%$ dan $1 \%$. Hal ini menunjukkan bahwa kemampuan berpikir tingkat tinggi siswa rendah. Rendahnya sikap ilmiah siswa ini diindikasi dengan jarangnya siswa mengajukan pertanyaan kepada guru dan seringnya siswa melakukan tindakan kecurangan pada saat ujian. Rendahnya sikap ilmiah ini berakibat sangat besar pada pendidikan kita saat ini.

Menurut Slameto (2003) sikap merupakan faktor pendukung yang mempengaruhi kemampuan kognitif siswa. Dimana sikap merupakan sesuatu yang juga dipelajari dan sikap menentukan bagaimana individu bereaksi terhadap suatu situasi. Sehingga siswa mampu menemukan apa yang dicari dalam kehidupan.

Sikap ilmiah diartikan pula sebagai penilaian umum seseorang atas suatu objek yang memiliki tipikal sains atau yang berhubungan dengan sains, disamping itu sikap merupakan fasilitator dan produk dari proses belajar kognitif menurut Dalyono (2005). Sikap ilmiah dalam proses pembelajaran antara lain sikap ingin tahu, respek, berpikir kritis, penemuan dan kreatif, berpikir terbuka, ketekuan dan peka terhadap lingkungan. Padahal sikap ilmiah ini memiliki peran tersendiri dalam memotivasi diri siswa dalam melaksanakan pembelajaran sains. Dengan memiliki sikap ilmiah, siswa akan terdorong untuk menggali lebih jauh untuk menjawab dari rasa ingin tahu yang dimiliki siswa.

Secara empiris, berdasarkan hasil analisis penelitian terhadap rendahnya kemampuan berpikir tingkat tinggi siswa disebabkan oleh dominannya proses pembelajaran konvensional. Pada pembelajaran ini suasana kelas cenderung teacher-centered sehingga siswa menjadi pasif menurut Trianto (2009). Metode pembelajaran yang digunakan guru sangat monoton sehingga kurang mampu meningkatkan aktivitas dan motivasi dalam mempelajari fisika, guru jarang memberikan kesempatan kepada siswanya untuk berinteraksi dengan temannya, dan sebagainya. Berhasil atau tidaknya suatu pendidikan dalam suatu negara salah satunya adalah 
karena guru. Guru mempunyai peranan yang sangat penting dalam perkembangan dan kemajuan anak didiknya. Salah satu model pembelajaran yang dapat diterapkan dalam pembelajaran fisika adalah model pembelajaran berbasis masalah (Problem Based Learning). Diknas (2013) menyebutkan pembelajaran berbasis masalah merupakan sebuah pendekatan pembelajaran yang menyajikan masalah kontekstual sehingga merangsang siswa untuk belajar. Pembelajaran berdasarkan masalah tidak dirancang untuk membantu guru memberikan informasi yang sebanyak-banyaknya kepada siswa, akan tetapi pembelajaran berbasis masalah dikembangkan untuk membantu siswa mengembangkan kemampuan berpikir, pemecahan masalah dan keterampilan intelektual, belajar berbagai peran orang dewasa melalui pelibatan mereka dalam pengalaman nyata dan menjadi pembelajaran yang mandiri. Hal ini didukung juga oleh Herman dalam Kharida (2009) yang menyatakan bahwa model pembelajaran berbasis masalah dipilih karena dalam proses pembelajaran siswa dihadapkan kepada masalah kehidupan nyata. Akibatnya, siswa mampu memecahkan masalah serta mendapat pengetahuan dan konsep penting.

Banyak ahli yang menjelaskan bentuk peranan model pembelajaran berbasis masalah. Salah satunya pendapat Johnson yang mengemukakan ada 5 langkah model pembelajaran berbasis masalah melalui kegiatan kelompok: (1) Mengidefinisikan masalah yaitu merumuskan masalah dari peristiwa tertentu yang mengandung isu konflik, hingga siswa menjadi jelas masalah apa yang akan dikaji, (2) Mendiagnosis masalah, yaitu menentukan sebab-sebab terjadinya masalah, serta menganalisis berbagai faktor, dari baik faktor yang bisa menghambat maupun faktor yang dapat mendukung dalam penyelesaian masalah, (3) Merumuskan alternatif strategi, yaitu menguji setiap tindakan yang telah dirumuskan melalui diskusi kelas, (4) Menentukan dan menerapkan strategi pilihan, yaitu pengambilan keputusan tentang strategi mana yang dapat dilakukan, (5) Melakukan evaluasi, baik evaluasi proses maupun evaluasi hasil. Evaluasi proses adalah evaluasi terhadap seluruh kegiatan, sedangkan evaluasi hasil adalah evaluasi terhadap akibat dari penerapan strategi yang diterapkan. Arends (2008) mengemukakan langkah-langkah melaksanakan pembelajaran berbasis masalah yaitu memberikan orientasi tentang permasalahan kepada siswa, mengorganisir siswa untuk meneliti, membantu investigasi mandiri dan kelompok, mengembangkan dan mempresentasikan arteifak dan exhibit, menganalisis dan mengevaluasi proses mengatasi masalah.

\section{METODE PENELITIAN}

Penelitian ini telah dilaksanakan di SMA Negeri 1 Perbaungan pada kelas X semester I Kabupaten Serdang Bedagai. Waktu penelitian dilakukan pada pelaksanaan proses pembelajaran atau pada proses kegiatan belajar mengajar semester ganjil tahun pembelajaran 2014/2015 yaitu tepatnya pada bulan Agustus s/d Oktober 2014. Populasi dalam penelitian ini adalah seluruh siswa kelas X IPA SMA Negeri I Perbaungan Kabupaten Serdang Bedagai dari empat kelas paralel/ruang belajar dengan jumlah keseluruhan 180 orang. Teknik pengambilan sampel digunakan dengan desain kelompok acak (cluster random sampling). Sampel yang diambil dalam penelitian tersebut terdiri dari dua kelas/kelompok, yaitu kelas X IPA 1 sebagai kelas eksperimen dan kelas X IPA 2 sebagai kelas kontrol.

Variabel ini melibatkan tiga macam variabel penelitian yaitu variabel terikat, variabel bebas dan variabel intervensi. Variabel terikat adalah hasil belajar siswa pada mata pelajaran fisika kelas X IPA SMA Negeri I Perbaungan Kabupaten Serdang Bedagai dari 4 paralel/ruang belajar semester ganjil T.P 2014/ 2015 pada ranah kognitif. Variabel bebas adalah model pembelajaran dengan menggunakan model pembelajaran berbasis masalah dengan menggunakan media flash, sedangkan variabel moderator adalah sikap ilmiah.

Rancangan penelitian yang akan digunakan adalah rancangan factorial $2 \times 2$, dengan alasan bahwa rancangan ini mempunyai keuntungan 
sebagai berikut (1) Memungkinkan pengujian hipotesis penelitian sekaligus di dalam satu eksprimen, (2) Memberikan kesempatan untuk menyelidiki interaksi yang sering begitu penting dalam penelitian pendidikan, (3) Memberikan pengujian yang lebih kuat terhadap hipotesis.

\section{HASIL PENELITIAN DAN PEMBAHASAN}

Setelah dilakukan penelitian maka diperoleh hasil penelitian yang kemudian dianalasis. Analisis yang dilakukan adalah melihat perbandingan kemampuan berpikir tingkat tinggi siswa untuk data pretes dan postes pada kelas eksperimen dan kelas kontrol. Hasil pretes postes kelas eksperimen dan kontrol terlihat seperti pada Tabel 1.

Tabel 1. Data Pretes-Postes kelas Ekspermen dan Kontrol

\begin{tabular}{ccc}
\hline Model & Kontrol & Eksperimen \\
\hline Pre Test & 33.55 & 35.8 \\
\hline Post test & 53.21 & 72.6 \\
\hline
\end{tabular}

Agar data hasil penelitian dapat dianalisis menggunakan uji parametrik, maka perlu dilakukan beberapa uji asumsi atau uji prasyarat. Syarat dapat diuji secara parametrik adalah data berdistribusi normal dan homogeny. Untuk itu terlebih dahulu data diuji normalitas dan homogenitasnya menggunakan bantuan SPSS 21.0. pada Tabel 2 dan 3 di bawah ini.

Tabel 2. Uji Normalitas

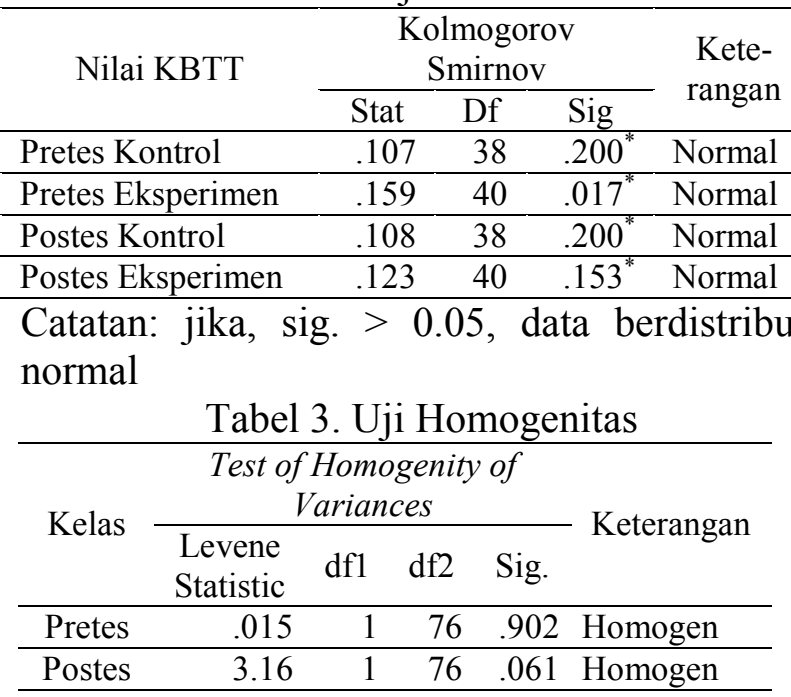

Catatan: jika, sig. $>0.05$, data homogen
Dari Tabel 2 dan 3 diperoleh hasil pretes dan postes kelas eksperimen dan kelas kontrol berdistribusi normal dan memiliki varians yang homogen. Selain itu data pretes juga telah diuji kesamaan rata-ratanya dengan uji t sebagai salah satu bukti bahwa kelas pre test siswa tidak berbeda.

Berdasarkan hasil analisis data diperoleh kesamaan awal dalam kemampuan berpikir tingkat tinggi siswa dengan hasil $t_{\text {hitung }} 1,233$ dan sig. (2-tailed) 0,221 ( $\mathrm{t}_{\text {tabel }}=1,664, \alpha=$ $0,05)$. Hasil ini menunjukkan bahwa $-t_{\text {tabel }} \leq$ $t_{\text {hitung }} \leq t_{\text {tabel }}$ dan nilai signifikansi lebih besar dibandingkan 0,05. Berdasarkan data dari nilai kemampuan berpikir tingkat tinggi siswa dikelompokkan menurut data sikap ilmiah dengan tujuan agar dapat melihat kemampuan berpikir tingkat tinggi siswa yang memiliki sikap ilmiah di bawah rata-rata dan diatas ratarata.

Pada gambar 2 diperoleh rata-rata kemampuan berpikir tingkat tinggi siswa yang memiliki sikap ilmiah diatas rata-rata pada kelas eksperimen sebesar 79.125 dan di kelas kontrol diperoleh rata-rata sebesar 53.833 Sebaliknya untuk kemampuan berpikir tingkat tingi siswa yang berada dibawah rata-rata pada kelas eksperimen sebesar 66.075 dan di kelas kontrol sebesar 52.575.

\section{Kelas Kontrol \&Eksperimen}

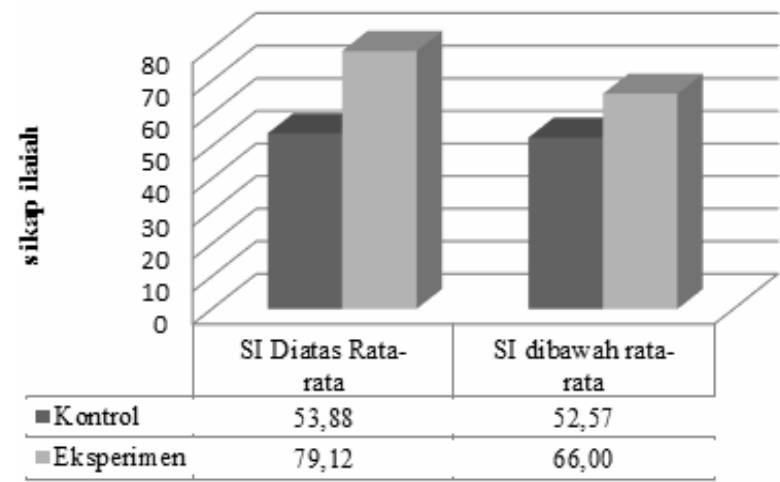

Gambar 1. Diagram Data KBTT siswa berdasarkan tingkat Sikap Ilmiah

Uji Hipotesis dapat dilakukan setelah pengelompokan siswa dilakukan dengan menggunakan analisis varians (Anava) dua jalur. 
Siswa SMA.

Tabel 5 berikut ini menyajikan hasil analisis Anava dengan bantuan SPSS 17.0.

Tabel 5. Hasil Uji Anava Dua Jalur

Dependent Variable: KBTT Postes

\begin{tabular}{lrrrrr}
\hline Source & $\begin{array}{c}\text { Type III Sum } \\
\text { of Squares }\end{array}$ & Df & Mean Square & F & \multicolumn{1}{l}{ Sig. } \\
\hline Corrected Model & $9074.124^{\mathrm{a}}$ & 3 & 3024.708 & 62.588 & .000 \\
Intercept & 307978.800 & 1 & 307978.800 & 6372.784 & .000 \\
Model & 7320.617 & 1 & 7320.617 & 151.480 & .000 \\
Sikap_Ilmiah & 7320.617 & 1 & 995.976 & 20.609 & .000 \\
Model * Sikap_Ilmiah & 676.427 & 1 & 676.427 & 13.997 & .004 \\
Error & 3576.213 & 74 & 48.327 & & \\
Total & 323556.750 & 78 & & & \\
Corrected Total & 12650.337 & 77 & & & \\
\hline
\end{tabular}

a. $R$ Squared $=.717$ (Adjusted $R$ Squared $=.705$ )

Berdasarkan rangkuman hasil perhitungan pada tabel 5 diperoleh nilai sig. model pembelajaran sebesar 0,000 . Karena nilai sig. $0,000<0,05$, maka hasil pengujian hipotesis menolak $\mathrm{H}_{0}$ atau menerima $\mathrm{H}_{\mathrm{a}}$ dengan taraf alpha 5\%, maka hipotesis penelitian menyatakan" Terdapat perbedaan kemampuan berpikir tingkat tinggi fisika siswa dengan pembelajaran konvensional dan model pembelajaran berbasis masalah dengan menggunakan media flash di kelas $\mathrm{X}$ SMA Negeri I Perbaungan.

Dari tabel 5 juga diperoleh nilai sig. sikap ilmiah sebesar 0,000. Karena nilai sig. 0,000< 0,05 sehingga memberikan keputusan menolak Ho pada taraf alpha 5\%, maka hipotesis penelitian menyatakan "Terdapat perbedaan kemampuan berpikir tingkat tinggi fisika siswa yang memiliki sikap ilmiah diatas rata-rata dan sikap ilmiah di bawah rata-rata di kelas X SMA Negeri I Perbaungan" teruji kebenarannya. Dari tabel 5 juga diperoleh nilai sig. sikap ilmiah sebesar 0,000. Karena nilai sig. 0,004<0,05, sehingga hasil pengujian hipotesis menolak Ho dan menerima Ha dalam taraf alpha 5\%, maka hipotesis penelitian yang menyatakan "Terdapat interaksi antara model pembelajaran berbasis masalah dengan media flash dan sikap ilmiah terhadap kemampuan berpikir tingkat tinggi fisika siswa di kelas X SMA Negeri I Perbaungan" teruji kebenarannya.

\section{Pembahasan}

Sesuai dengan hasil penelitian yang dilakukan bahwa siswa yang diajar dengan model pembelajaran berbasis masalah menggunakan flash memperoleh skor rata-rata yang lebih tinggi dibandingkan dengan siswa yang diajar dengan model pembelajaran konvensional. Hasil penelitian ini sesuai dengan hasil penelitian dari Gamze (2013) yang menyimpulkan bahwa pembelajaran fisika dengan menggunakan metode PBL dibandingkan dengan metode tradisional terbukti lebih efektif untuk meningkatkan keberhasilan dalam fisika.sama halnya pada penelitian Kusuma (2012) mengatakan bahwa terdapat perbedaan prestasi belajar siswa dengan pembelajaran berbasis masalah menggunakan multimedia dengan menggunakan modul. Hasil ini menunjukkan bahwa penggunaaan strategi belajar dan pendekatan PBL membatu perkembangan keberhasilan guru.

Sikap ilmiah mempunyai pengaruh yang kuat terhadap perilaku dan belajar siswa, karena sikap itu membantu siswa dalam merasakan dunianya dan memberikan pedoman kepada prilaku yang dapat membantu dalam menjelaskan dunianya. Hal ini senada dengan Naelal (2013) mengatakan bahwa sikap ilmiah mempunyai pengaruh yang kuat terhadap perilaku dan belajar siswa. juga membantu seseorang merasa aman di suatu lingkungannya yang pada mulanya tampak asing. Setelah dilakukan 
pengamatan terhadap sikap ilmiah, terlihat bahwa sikap ilmiah mempengaruhi kemampuan berpikir tingkat tinggi siswa. Sikap merupakan sesuatu yang dipelajari, dan sikap menentukan bagaimana individu bereaksi terhadap situasi serta menentukan apa yang di cari individu dalan kehidupan. Kurangnya sikap positif siswa dalam belajar dapat menyebabkan rendahnya kemampuan berpikir siswa. Telah dijelaskan sebelumnya bahwa sikap ilmiah sangat mendukung kegiatan belajar siswa ke arah yang positif. Jadi dapat disimpulkan bahwa tingkat sikap ilmiah yang dimiliki seorang siswa dapat mempengaruhi kemampuan berpikir tingkat tinggi siswa yang dalam hal ini adalah kemampuan berpikir matematikanya. Hal yang senada terdapa pada penelitian Intrati (2014) mengatakan bahwa sikap ilmiah sangat penting dikembangkan karena dapat mempengaruhi kemampuan berpikir siswa dikarenakan siswa kurang memantapkan ilmu yang telah diajarkan serta malas berpartisipasi selama kegaiatan pembelajaran berlangsung.

Pemakaian model pendekatan belajar dalam pembelajaran Fisika harus mempertimbangkan tingkat sikap ilmiah yang dimiliki oleh siswa. Berdasarkan temuan dalam penelitian ini mendapatkan hasil bahwa siswa yang memiliki sikap ilmiah di atas rata-rata akan lebih tinggi kemampuan berfikir tingkat tingginya jika diajar dengan model pembelajaran berbasis masalah menggunakan media flash dibandingkan diajar dengan model pembelajaran konvensional. Sebaliknya untuk siswa yang memiliki sikap ilmiah dibawah rata-rata, kemampuan berfikir tingkat tingginya lebih tinggi jika diajar dengan menggunakan model pembelajaran konvensional dibandingkan jika diajar dengan menggunakan model pembelajaran berbasis masalah menggunakan multimedia flash. Hal ini senada dengan penelitian Urip (2013) yang mengatakan bahwa sikap ilmiah siswa yang belajar menggunakan model pembelajaran berbasis masalah (PBL) lebih baik daripada siswa yang belajar menggunakan model konvensional

\section{KESIMPULAN}

Sesuai dengan hasil dan pembahasan penelitian yang telah diuraikan, maka dapat ditarik kesimpulan dalam penelitian ini yaitu: (1) terdapat perbedaan perbedaan kemampuan berpikir tingkat tinggi fisika siswa antara siswa yang diajar dengan model pembelajaran konvensional dengan siswa yang diajar dengan model pembelajaran berbasis masalah menggunakan media flash. Kelompok siswa yang diajar dengan model pembelajaran berbasis masalah menggunakan media flash memiliki kemampuan berpikir tingkat tinggi yang lebih tinggi dibandingkan dengan kelompok siswa yang diajar dengan model pembelajaran konvensional. (2)Terdapat perbedaan berpikir tingkat tinggi antara siswa yang memiliki sikap ilmiah diatas rata-rata dengan siswa yang memiliki sikap ilmiah di bawah rata-rata. Kelompok siswa yang memiliki sikap ilmiah diatas rata-rata memiliki kemampuan berpikir tingkat tinggi yang lebih baik dibandingkan dengan siswa yang memiliki sikap ilmiah di bawah rata-rata. (3) Terdapat interaksi antara model pembelajaranberbasis masalah dan dan sikap ilmiah terhadap kemampuan berpikir tingkat tinggi fisika siswa. Kelompok siswa yang memiliki sikap ilmiah di atas rata-rata lebih tinggi kemampuan berpikir tingkat tingginya jika diajar dengan menggunakan model pembelajaran berbasis masalah menggunakan flash dibandingkan jika diajar dengan model pembelajaran konvensional. Kemudian sebaliknya, untuk kelompok siswa yang memiliki sikap ilmiah di bawah rata-rata lebih tinggi kemampuan berpikir tingkat tingginya jika diajar dengan menggunakan model pembelajaran konvensional bila dibandingkan dengan diajar dengan menggunakan model pembelajaran berbasis masalah menggunakan media flash.

\section{DAFTAR PUSTAKA}

Arends, R. 2008. Learning to Teach (7 $7^{\text {th }}$ ed.). Belajar untuk Mengajar (Terjemahan Helly Prajitno Soetjipto dan Sri Mulyantini Soetjipto pada Tahun 2008). Yogyakarta: Pustaka Pelajar. 
Ayu, H. 2013. Efektivitas Model Pembelajaran Berbasis Masalah Berbasis Software power point, makromedia Flash, dab Cabri II Plus Terhadap Hasil Belajar Siswa. Universitas Semarang.

Dalyono, M. 2005. Psikologi Pendidikan. Jakarta: Rineka Cipta.

Gamze, S. 2013. A Comparison Of Achievement In Problem Based Strategic And Traditional Learning Classes In Physics. International Journal On New Trends In Education And Their Implications.

Intrati, A. 2014. Upaya Meningkatkan Sikap Ilmiah Dan Hasil Belajar Dengan Menggunakan Model Pembelajran Problem Based Learning Di kelas X SMA Neheri 8 Kota Jambi. Universitas Jambi.

Kharida, L. 2009. Penerapan Pembelajaran Berbasis Masalah Untuk Peningkatan Hasil Belajar Siswa Pada Pokok Bahasan Elastisitas Bahan.

Kusuma, W. 2012. Pembelajaran Fisika Dengan Model Problem Based Learning Menggunakan Multimedia Dan Modul
Ditinjau Dari Kemampuan Berpikir Abstrak Dan Kemampuan Verbal Siswa. Universitas Surakarta.

Muslim. 2004. Pengembangan Model Pembelajaran Kontekstual Dan Implikasinya Terhadap Peningkatan Kualitas Pembelajaran Fisika Di SMA.

Naelal, N. 2013. Peningkatan Sikap Ilmiah Dan Ketuntasan Hasil Belajar Fisika Menggunakan Pendekatan Acclerated Learning Melalui Metode Eksperimen Di kelas VII E SMP Negeri 3 Silo Tahun Ajaran 2012/2013. Universitas Jember.

Slameto. 2003. Belajar dan Faktor-Faktor Yang Mempengaruhinya. Jakarta: Rineka Cipta.

Trianto. 2009. Mendesain Model Pembelajaran Inovatif-Progresif: Landasan, dan Implementasinya Pada Kurikulum Tingkat Satuan Pendidikan. Surabaya: Penerbit Kencana.

Urip, A. 2013. Pengaruh Model Pembelajaran Berbasis Masalah Terhadap Sikap Ilmiah Dan Keterampilan Berpikir Kritis. Balik Papan: Universitas Pendidikan Ganesha. 